\title{
ANALISIS RISIKO PRODUKSI SAYURAN DAUN INDIGENOUS di KECAMATAN KADUDAMPIT, KABUPATEN SUKABUMI, JAWA BARAT
}

\author{
Syaima L Mubarokah ${ }^{1}$, W. Nahraeni ${ }^{1}$, A. Yusdiarti $^{1}$, A. Rahayu ${ }^{2}$ \\ ${ }^{1}$ Jurusan Agribisnis, Fakultas Pertanian Universitas Djuanda Bogor \\ ${ }^{2}$ Jurusan Agroteknologi, Fakultas Pertanian Universitas Djuanda Bogor \\ Jl. Tol Ciawi No 1 Universitas Djuanda Bogor Kode Pos 16720 \\ ${ }^{a}$ Korespondensi: Syaima L Mubarokah. Telp: 089634529446; E-mail: \\ syaima.laila@gmail.com
}

\begin{abstract}
This study aims to identify 1) the source of production risk in some indigenous leaf vegetables, especially basil 2) the level of risks encountered, and 3) formulate strategies to control the risk of production of indigenous leaf vegetable. The research was conducted in Kecamatan Kadudampit Sukabumi, the method of sampling used simple random sampling. The number of farmers were 42 farmers. In specialization activities, the method to process risk data used are analysis of variance, standard deviation and coefficient of variation. The results showed that the source of production risk faced by farmers were weather / climate, pest and disease diseases and seed quality. The expected return value of basil commodity Rp.1.801.204 with the risk level of losses was 0.382 or $38 \%$. Strategies that could be done to reduced the risk was the diversification activity with . timing and appropriate commodities of diversification activities, plan intercropping cropping pattern between two combination basil with lettuce were $60 \%$ and $40 \%$ and basil with gourd were $60 \%$ and $40 \%$, risk management in production through preventive strategies with improvement of physical facilities and mitigation strategies with pest and disease controls encountered.
\end{abstract}

Keywords: basil, variance analysis, standard deviation, coefficient of variation, risk management.

\begin{abstract}
ABSTRAK
Penelitian ini bertujuan untuk mengidentifikasi sumber risiko produksi pada sayuran daun indigenous khususnya kemangi, tingkat risiko yang dihadapi, serta merumuskan strategi untuk mengendalikan risiko produksi sayuran daun indigenous. Penelitian dilakukan di Kecamatan Kadudampit Kabupaten Sukabumi. Metode penarikan sampel menggunakan simple random sampling dengan jumlah petani sampel sebanyak 42 orang petani. Metode analisis data menggunakan analisis varian, standar deviasi dan koefisien variasi. Hasil penelitian menunjukkan bahwa sumber risiko produksi yang dihadapi oleh petani adalah cuaca/iklim, gangguan hama dan penyakit dan kualitas benih. Nilai expected return komoditas kemangi adalah Rp.1.053.137 dengan tingkat risiko kerugian sebesar 0,382 atau $38 \%$. Strategi yang dapat dilakukan untuk mengurangi risiko adalah dengan melakukan kegiatan diversifikasi dengan pola tanam secara tumpang sari antara dua kombinasi komoditas contoh kemangi dengan selada sebesar $60 \%$ dan $40 \%$, manajemen risiko dalam budidaya melalui strategi preventif dengan perbaikan fasilitas fisik dan strategi mitigasi dengan pengendalian hama dan penyakit yang dihadapi.
\end{abstract}

Kata Kunci : Kemangi, Analisis Varian, Standar Deviasi, Koefisien Variasi, Manajemen Risiko. 


\section{PENDAHULUAN}

Sayuran indigenous merupakan bagian dari keanekaragaman hayati yang dimiliki Indonesia. Sayuran ini banyak ditanam atau dibudidayakan di pekarangan rumah, tetapi saat ini sudah banyak petani yang membudidayakannya secara komersial pada lahan terbuka walaupun masih terbatas pada lokasi tertentu (Suryadi dan Kusmana, 2013). Jenis sayuran daun indigenous yang banyak ditanam antara lain kemangi, katuk, pohpohan, reundeu, leunca, kecipir dan sebagainya. Namun demikian, sayuran ini cenderung masih terabaikan (Permatasari, 2013). Fakta di lapangan menunjukkan di beberapa daerah, permintaan sayuran indijenes relatif rendah, walaupun di daerah tersebut para petani terus meningkatkan produksinya, namun hanya sebatas untuk memenuhi konsumsi keluarga. Namun seiring dengan kesadaran masyarakat akan nilai gizi keluarga dan pentingnya zat yang terkandung di dalam Sayuran indijenes, produk Sayuran daun telah meluas dan semakin dikomersialisasikan

Menurut Soetiarso (2010), yang menjadi kendala dalam usahatani sayuran indigenous di Indonesia diantaranya adalah: 1) kurangnya benih yang dibutuhkan, terutama benih yang telah bersertifikasi, 2) kurangnya informasi mengenai teknologi budidaya, dan 3) kurangnya informasi mengenai kesesuaian sayuran indigenous dengan sistem produksi yang ada.

Sayuran indijenes memiliki potensi bisnis yang baik, namun belum teroptimalkan. Seiring dengan perkembangan rumah makan Sunda di Jawa Barat yang banyak menyajikan lalapan sebagai menu, menunjukkan adanya peningkatan permintaan untuk tanaman ini. Permintaan sayuran indigenous terutama di Jawa Barat terus meningkat. Hal ini terbukti dari beragamnya jenis sayuran daun indigenous seperti kemangi, poh-pohan, reundeu dan katuk yang dijual di pasar tradisional maupun swalayan besar di Bogor dan Sukabumi. Selain itu dengan meningkatnya perkembangan rumah makan Sunda di Jawa Barat (khususnya yang menyediakan lalaban) merupakan salah satu indikasi meningkatnya permintaan sayuran tersebut.

Di sisi lain peningkatan produksi tidak secepat peningkatan konsumsi untuk beberapa sayuran indigenous. Berdasarkan survei di lapangan, ternyata keluhan terbanyak yang dirasakan oleh petani sayuran indigenous adalah gangguan hama penyakit dan perubahan cuaca serta iklim. Hal ini mengakibatkan adanya fluktuasi produksi pada sayuran indigenous yang mengindikasikan adanya risiko produksi. Fluktuasi produksi menyebabkan adanya fluktuasi harga dan menimbulkan fluktuasi pendapatan yang pada akhirnya akan mempengaruhi kesejahteraan petani.

Risiko adalah probabilitas suatu kejadian yang mengakibatkan kerugian ketika kejadian itu terjadi selama periode tertentu (Badariah et al, 2012). Kehadiran risiko di bidang pertanian memiliki pengaruh yang signifikan terhadap keputusan produksi dan investasi petani, sehingga dibutuhkan suatu konsep manajemen risiko yang baik.

Menurut Crane et al. (2013) di sektor pertanian terdapat lima sumber utama risiko usaha, yaitu: (a) risiko produksi atau teknis, (b) risiko pasar atau harga, (c) risiko teknologi, (d) risiko legal atau sosial, dan (e) risiko karena kesalahan manusia (Kahan, 2013). Kelima sumber risiko tersebut dapat menimbulkan efek jangka pendek maupun jangka panjang terhadap usahatani.

Kecamatan Kadudampit merupakan kecamatan di Kabupaten Sukabumi yang banyak membudidayakan sayuran indigenous dengan sentra produksi berlokasi di Desa Undrusbinangun dan Sukamaju. Menurut kondisi di lapangan, sayuran indigenous khususnya komoditas kemangi, saat ini banyak mengalami kendala produksi yang disebabkan oleh hama dan penyakit yang banyak 
bermunculan seperti ulat rayap yang menyerang batang dan akar sehingga tanaman mudah rubuh. Kendala lainnya adalah teknik budidaya komoditas kemangi yang sudah berbeda dengan teknik budidaya sebelumnya. Saat ini penggunaan input pupuk pada kemangi sudah menggunakan pupuk kimiawi atau sudah tidak organik sehingga menyebabkan ketidakseimbangan pada lahan dan berisiko kegagalan. Berdasarkan permasalahan di atas maka penting untuk dikaji mengenai risiko produksi sayuran daun indigenous sebagai bentuk pelestarian dari tanaman tersebut.

Penelitian ini bertujuan untuk mengidentifikasi sumber risiko produksi yang dihadapi oleh sayuran indigenous, menganalisis tingkat risiko usahatani sayuran indigenous secara spesialisasi dan alternatif strategi yang dilakukan petani dalam menangani risiko usaha sayuran indigeneus.

\section{BAHAN DAN METODE}

Penelitian dilakukan di Desa Undrusbinangun dan Desa Sukamaju, Kecamatan Kadudampit, Kabupaten Sukabumi. Metode yang digunakan dalam penelitian ini adalah metode kuantitatif. Pengambilan sampel menggunakan metode simple random sampling dengan jumlah sampel sebanyak 42 orang petani sayuran indigenous kemangi.

Pengambilan data dilakukan dengan teknik wawancara menggunakan kuisioner yang telah dtentukan. Analisis kuantitatif digunakan untuk mengetahui sumber-sumber risiko produksi yang dihadapi oleh petani sayuran indigenous. Untuk menjawab tujuan pertama digunakan metode Skala Likert yaitu pemberian skor sumber risiko menggunakan skala likert dari angka 1 sampai dengan 5 yaitu 1=Sangat tidak berpengaruh, 2=Tidak berpengaruh, 3=Cukup berpengaruh, 4=Berpengaruh, $5=$ Sangat berpengaruh.
Selanjutnya data ditabulasi dan dianalisis menggunakan rumus interval kelas sebagai berikut (Sugiono, 2011) :

$$
\mathrm{I}=\mathrm{R} / \mathrm{K}
$$

Keterangan :

$\mathrm{I}=$ Interval

$\mathrm{R}=$ Range antara skor tertinggi dengan

terendah

$\mathrm{K}=$ Jumlah alternatif jawaban setiap item

Dalam menganalisis risiko beberapa pendekatan telah digunakan antara lain: koefisien variasi (coefficient variation), ragam (variance) dan simpangan baku (standard deviation). Ketiga pengukuran tersebut digunakan untuk mengukur pengaruh sumber-sumber risiko, yang berkaitan satu sama lain. Risiko akan semakin kecil dengan semakin kecilnya nilai ketiga indicator tersebut (Saptana, 2010; Fauziah, 2010).

Untuk menjawab tujuan kedua digunakan pengukuran peluang, expected returm, analisis variance, standard deviation dan coeffisien variation. Untuk memperoleh nilai peluang dan expected return dapat dituliskan dengan rumus :

$$
\mathrm{Pi}=\frac{f}{\mathrm{~T}}
$$

Keterangan :

$\mathrm{P}=$ Peluang $\mathrm{f}=$ Frekuensi kejadian $\mathrm{T}=$ Periode waktu proses produksi

$$
\mathrm{E}(\mathrm{Rj})={ }_{i=1}^{n} P i j . R i j
$$

Keterangan :

$$
\begin{array}{ll}
\mathrm{E}(\mathrm{Rj}) & =\text { Expected return } \\
\mathrm{Pi} & =\text { Peluang suatu kejadian } \quad \mathrm{i}= \\
& \text { kemangi) } \\
\mathrm{N} & =\text { Frekuensi kejadian } \\
\mathrm{Ri} & =\text { return/nilai berdasarkan } \\
& \text { pendapatan (sayuran kemangi,) }
\end{array}
$$$$
(\sigma \mathrm{i}) 2={ }_{j=1}^{n} \text { Pij. }(R i j-R i)
$$

Keterangan :

$\left(\sigma_{\mathrm{i}}\right)^{2}=$ variance dari return komoditas

$\mathrm{Ri}=$ expected return komoditas kemangi.

$$
\sigma i=\sqrt{ }(\sigma i) 2
$$

Keterangan :

$\sigma_{\mathrm{i}}^{2} \quad=$ varian komoditas kemangi. 
$\sigma_{\mathrm{i}} \quad=$ standar deviasi kemangi.

$$
C V=\frac{\sigma i}{R i}
$$

Keterangan :

$\mathrm{CVi}=$ coefficient variation komoditas kemangi.

\section{HASIL DAN PEMBAHASAN}

\section{Pola Tanam Sayuran}

Petani di Kecamatan Kadudampit melakukan pola tanam yang beragam, dengan mengusahakan lebih dari satu jenis tanaman dengan komoditas utama dan poh-pohan serta reundeu sebagai komoditas selingan. Penanaman sayuran yang dilakukan oleh petani biasanya dilakukan dengan pola tanam monokultur, tumpangsari dan tumpang gilir.

\section{Karakteristik Petani}

Dari 42 orang petani sampel, petani rata-rata berumur antara $30-60$ tahun. Hal ini mengindikasikan rata-rata umur petani sayuran indigenous masih dalam kisaran umur produktif. Sebagian besar $(33 \%)$ petani berumur antara 51 sampai dengan 60 tahun.

Petani sayuran indigenous sebagian besar berjenis kelamin laki-laki (86 persen), menunjukkan bahwa laki-laki memiliki tanggung jawab dalam pengambilan keputusan. Tingkat pendidikan yang ditempuh petani sebagian besar hanya mampu menyelesaikan pendidikan hingga tingkat Sekolah Dasar (SD)/sederajat sebesar 55 persen namun tidak ada petani yang menyelesaikan pendidikan sampai dengan Perguruan Tinggi.

Pengalaman petani dalam bertani sebagian besar lebih dari 10 tahun (81 persen). Sedangkan lamanya pengalaman petani menanam sayuran indigenous sebagian besar berkisar antara 1 sampai 5 tahun dengan (50 persen). Jumlah tanggungan keluarga berkisar antara $0-2$ orang (48\%), 3-5 orang (48\%). Beban tanggungan keluarga yang rendah akan mengurangi biaya pengeluaran petani.
Luas lahan yang digarap petani sebagian besar ( 57\%) kurang dari 0,25 ha dan hanya $5 \%$ petani menggarap lahan lebih dari 1 ha. Sebagian besar (69\%) meerupakan lahan milik sendiri, sisanya meerupakan lahan sewa. Karakteristik petani sayuran dapat dilihat pada Lampiran 1.

\section{Teknik Budidaya}

Luas lahan kemangi yang digarap petani rata-rata $540 \mathrm{~m}^{2}(25,715)$ dari luas lahan total yang digarap. Jenis kemangi yang dibudidayakan adalah kemangi berdaun besar. Hal ini disesuaikan dengan banyaknya permintaan konsumen yang menginginkan kemangi berdaun besar

Dalam melakukan budidaya kemangi, para petani di daerah penelitian menggunakan pupuk organik dan non organik serta beberapa jenis pestisida. Pupuk yang digunakan adalah pupuk kandang, urea, phonska, TSP dan ZA. Pestisida yang biasa digunakan petani kemangi adalah Amistartop, Victory, Drusband, Prepaton dan Antracol. Jumlah

Menurut hasil wawancara, panen kemangi dilakukan satu kali dalam seminggu dan masa produktifnya adalah 6 bulan. Biaya pengikatan kemangi dan selada dihitung per hasil dengan upah sebesar Rp. 2000 per gabung. Kemangi dipanen oleh petani sesuai dengan permintaan tengkulak di desa tersebut, sehingga petani belum dapat menentukan secara mandiri berapa jumlah ikat kemangi yang akan dipanen. Petani menggunakan tenaga kerja luar keluarga tidak tetap dengan pemberian upah harian. Pemberian upah tenaga kerja di Kecamatan Kadudampit dihitung sesuai jumlah jam kerja sebanyak delapan jam kerja per hari mulai dari pukul 07.00 sampai pukul 15.00 dengan upah tenaga kerja pria sebesar Rp. 50.000,- dan wanita sebesar Rp. 30.000,-.

Berbeda dengan kemangi, usahatani poh-pohan dan reundeu lebih mudah untuk dilakukan, tetapi jumlah permintaan komoditas tersebut masih sedikit di pasaran. Poh-pohan dan reundeu 
cenderung tahan terhadap hama dan penyakit sehingga dalam pemeliharaannya tidak perlu dilakukan pemberian pestisida. Poh-pohan dan reundeu biasanya ditanam sebagai tanaman selingan saja. Usahatani komoditas tersebut rata-rata menggunakan lahan bukan milik sendiri dan bukan sewa tetapi lahan Hak Guna Usaha. Masa panen tanaman poh-pohan dan reundeu dapat berkisar antara 4 sampai dengan 5 tahun bahkan dapat lebih dari 5 tahun selama lingkungan tempat poh-pohan dan reundeu tumbuh tercukupi oleh air.

\section{Biaya Produksi, Penerimaan dan Pendapatan Sayuran Indigenous}

Biaya produksi dan pendapatan beberapa sayuran indigenous berbeda-beda karena adanya perbedaan penggunaan input yang dapat dilihat pada Lampiran 2.

Dibandingkan dengan poh-pohan dan reundeu, kemangi merupakan sayuran indigenous yang mengeluarkan biaya terbesar. Hal ini disebabkan budidaya kemangi sudah menggunakan pupuk kimia dan pestisida sehingga biaya yang dibutuhkan lebih besar. Sementara pohpohan dan reundeu tumbuh secara alami dan tidak menggunakan banyak pupuk kimia dan pestisida.

Penerimaan total kemangi dalam satu periode produksi (6 bulan) sebesar $\mathrm{Rp}$ 11.404.615,- dengan biaya produksi sebesar Rp 5.518.162,- maka diperoleh pendapatan sebesar Rp5.886.453. $\mathrm{RC}=$ 2,06, artinya usahatani kemangi layak untuk diusahakan. Penerimaan kemangi jauh lebih besar dibandingkan dengan sayuran indigenous lainnya karena dapat dipanen setiap satu minggu atau sepuluh hari sekali. Berdasarkan hasil wawancara di lapangan, pada bulan kedua produksi, petani sudah dapat menutup modal dengan penerimaan yang diperoleh dari penjualan kemangi sehingga pada bulan ketiga produksi sampai tanaman mati, petani memperoleh keuntungan murni dari hasil produksi.

\section{Analisis Risiko \\ Sumber-Sumber Risiko}

Risiko produksi yang mengganggu usahatani dapat disebabkan oleh beberapa faktor diantaranya perubahan iklim/cuaca, gangguan hama dan penyakit serta kualitas pada benih yang digunakan. Lampiran 3 menunjukkan sumber risiko produksi yang paling berpengaruh terhadap hasil produksi, sumber risiko produksi yang dihadapi oleh petani dianalisis menggunakan Skala Likert dengan skala interval sebagai berikut:

$$
\begin{array}{ll}
42-75,6 & =\text { Sangat tidak berpengaruh } \\
75,6-109,2 & =\text { Tidak berpengaruh } \\
109,2-142,8 & =\text { Cukup berpengaruh } \\
142,8-176,4 & =\text { Berpengaruh } \\
176,4-210 & =\text { Sangat berpengaruh }
\end{array}
$$

a) Iklim/ Cuaca

Cuaca yang tidak mendukung akan menimbulkan serangan hama penyakit sehingga menyebabkan produksi sayuran menurun. Berdasarkan perhitungan dengan skala Likert, perubahan cuaca atau iklim memiliki skor tertinggi sebesar 201 artinya perubahan cuaca atau iklim sangat berpengaruh terhadap hasil produksi Sayuran indigenous. Berdasarkan informasi di lapangan, akhir-akhir ini musim hujan tidak dapat diprediksi seperti keadaan sebelumnya, sehingga menyebabkan penurunan produksi pada sayuran yang diusahakan oleh petani. Unsur-unsur penting dari hujan juga berhubungan dengan pertumbuhan hama dan penyakit seperti volume curah hujan, jumlah hari hujan dan intensitas hujan sehingga berpengaruh terhadap pertumbuhan hama dan penyakit.

b) Serangan Hama dan Penyakit

Penyakit yang sering muncul pada kemangi dan selada saat musim hujan adalah busuk daun dan batang disebabkan oleh bakteri Rhizoctonia solani. Penyakit ini menyebabkan daun memiliki bintihbintik berwarna hitam sehingga hasil panen menurun. Adanya penyakit pada sayuran indigenous khususnya kemangi dapat menyebabkan kerugian karena selain 
dapat mengurangi produksi maupun kualitas, juga dapat menyebabkan kegagalan panen. Hasil perhitungan skor skala Likert sebesar 195 menunjukkan bahwa serangan hama dan penyakit sangat mempengaruhi hasil produksi sayuran indigenous.

c) Kualitas Benih

Salah satu faktor yang menjadi penyebab tinggi atau rendahnya produksi dari sayuran adalah tergantung dari kualitas benih yang digunakan. Budidaya sayuran indigenous juga dipengaruhi oleh kualitas benih, dengan skor sebesar 171 . Benih berkualitas akan lebih tahan terhadap serangan hama dan penyakit dan memiliki tingkat viabilitas dan vigor yang baik.

\section{Analisis Risiko Usaha Sayuran Indigenous}

Perhitungan pada penilaian risiko menggunakan data berdasarkan tingkat pendapatan yang diperoleh dan peluang dalam kegiatan budidaya sayuran. Hasil perhitungan peluang sayuran daun indigenous dapat dilihat pada Tabel 1 yang dihitung berdasarkan persamaan 2 .

Tabel 1 Tingkat Peluang Berdasarkan Pendapatan Petani Per Satuan Lahan $3200 \mathrm{~m}^{2}$

\begin{tabular}{clcc}
\hline Komoditas & Kejadian & Peluang & Pendapatan $($ Rp) \\
\hline \multirow{2}{*}{ Kemangi } & Normal & 0,460 & 1.004 .524 \\
& Tertinggi & 0,287 & 1.606 .160 \\
& Terendah & 0,252 & 516.190 \\
\hline
\end{tabular}

Setelah dilakukan pengukuran peluang dari tingkat pendapatan, maka dilakukan perhitungan expected return. Tabel 2 menunjukkan bahwa pengembalian pendapatan kemangi yaitu Rp. 1.053.137 seperti pada persamaan 3.

\section{Analisis Risiko pada Kegiatan Spesialisasi \\ Nilai coefficient variation} menunjukkan besarnya tingkat risiko pada masing-masing komoditas. Semakin besar nilai coefficient variation maka risiko yang dihadapi oleh usahatani tersebut semakin

Tabel 2 Analisis Risiko Produksi Berdasarkan Pendapatan pada Sayuran Daun Indigenous

\begin{tabular}{llr}
\hline No & \multicolumn{1}{c}{ Keterangan } & Nilai \\
\hline 1 & Expected return & $1.053 .137,00$ \\
2 & Variance & $161.525 .733 .522,00$ \\
3 & Standard deviation & $401.902,64$ \\
4 & Coefficient variation & 0,382 \\
\hline
\end{tabular}

besar begitupun sebaliknya seperti yang dijelaskan pada persamaan 4, 5 dan 6 .

Hasil perhitungan nilai variance dan coefficient variation menunjukkan bahwa kemangi memiliki nilai coefficient variation sebesar 0,382 artinya peluang kerugian yang akan dihadapi oleh usahatani kemangi adalah sebesar 38 persen yang disebabkan adanya perubahan cuaca, serangan hama penyakit dan sumber risiko lainnya. Angka ini menunjukkan juga risiko yang diterima petani kemangi adalah sebesar 38 persen dari nilai penerimaan yang diperoleh petani

Berdasarkan informasi yang diperoleh saat wawancara dengan petani, komoditas kemangi merupakan salah satu sayuran indigenous yang telah banyak dikonsumsi dan diserap oleh pasar dibandingkan dengan sayuran indigenous lainnya sehingga banyak petani yang beralih untuk memproduksi kemangi 
karena besarnya keuntungan yang diperoleh jika berhasil mengusahakan komoditas tersebut. Saat ini kemangi sudah dibudidayakan secara komersial di daerah Kecamatan Kadudampit, cuaca dan iklim khususnya musim hujan yang tidak dapat diprediksi dengan mudah juga menjadi salah satu faktor adanya risiko produksi pada kemangi sehingga beberapa petani mengalami kerusakan produksi akibat faktor tersebut.

\section{Strategi Pengelolaan Risiko}

Strategi pengelolaan risiko yang dapat diterapkan pada petani terkait dengan besaran risiko yang dihadapi antara lain:

a. Pembuatan Jadwal Pola Tanam

Mengingat pola tanam yang dilakukan oleh petani masih belum intensif karena masih hanya berdasarkan kebiasaan dan permintaan saja, maka perlu dilakukan penjadwalan penanaman yang lebih intensif pada kegiatan usahatani yang diharapkan dapat memperoleh hasil yang lebih baik. Selain itu, petani sebaiknya melakukan diversifikasi pada usahataninya sehingga dapat mengefisienkan biaya dalam penggunaan tenaga kerja yang digunakan.

b. Manajemen Usahatani

Pengelolaan risiko pada usahatani sayuran indigenous dapat dilakukan dengan kegiatan preventif atau kegiatan menghindari terjadinya risiko. Hasil sebelumnya menunjukkan bahwa risiko paling tinggi disebabkan oleh iklim dan cuaca, salah satu kegiatan prefentif adalah memasang atau memperbaiki fasilitas fisik, yaitu membuat greenhouse sederhana untuk setiap usahatani sayuran indigenous agar dapat terlindungi dari curah hujan atau temperatur yang tinggi yang dapat menyebabkan penurunan produksi pada usahatani sayuran indigenous.

Greenhouse untuk daerah tropis sangat memungkinkan dan mempunyai banyak keuntungan dalam produksi dan budidaya tanaman. Produksi dapat dilakukan sepanjang tahun, dimana produksi dalam lahan yang terbuka tidak memungkinkan karena adanya hujan yang sering dan angin yang kencang.

c. Pengendalian Hama Penyakit

Penanganan hama dan penyakit dapat dilakukan dengan cara: a) sanitasi lingkungan yang dilakukan secara rutin dan lebih intensif; b) pengaturan rotasi tanaman yang lebih tepat misalnya menanam tanaman dengan family yang berbeda untuk memutus siklus hidup hama; dan c) sifat pengendalian terhadap hama penyakit yaitu dengan pencegahan sebelum hama penyakit tersebar ke tanaman.

Petani sudah melakukan beberapa cara untuk mengendalikan hama dan penyakit, tetapi upaya yang dilakukan oleh petani belum optimal. Hal ini disebabkan oleh hama dan penyakit yang menyerang tanaman tersebut tidak selalu sama tetapi sering berubah dari waktu ke waktu. Oleh sebab itu juga perlu dilakukan penyuluhan mengenai budidaya sayuran indigenous di Kecamatan Kadudampit.

d. Penggunaan Benih Bersertifikat dan Perawatan Sayuran secara Intensif

Benih bersertifikat memiliki daya tahan terhadap serangan hama dan penyakit dan perawatan intensif juga diperlukan dengan jadwal yang ditetapkan oleh petani untuk meningkatkan produksi dan kualitas sayuran.

\section{KESIMPULAN DAN IMPLIKASI KEBIJAKAN}

\section{Kesimpulan}

Sumber-sumber risiko produksi yang paling berpengaruh terhadap hasil produksi adalah cuaca yang sulit diprediksi, serangan hama penyakit dan benih yang belum bersertifikat. Tingkat risiko pada kegiatan spesialisasi kemangi diperoleh nilai $38 \%$

Strategi yang dapat dilakukan petani untuk mengurangi risiko produksi adalah melalui pembuatan jadwal pola tanam, manajemen risiko dalam budidaya, 
pengendalian hama penyakit, penggunaan benih bersertifikat serta melakukan kegiatan perawatan sayuran secara optimal.

\section{Implikasi Kebijakan}

Perlu adanya kerjasama dengan

Dinas Pertanian setempat mengenai pengelolaan risiko produksi dan cara budidaya pada sayuran indigenous khususnya kemangi dengan memberikan penyuluhan terkait budidaya dan pemasaran sayuran indigenous kepada petani. Petani dapat melakukan pengelolaan risiko dengan cara mengatur pola tanam dan menggunakan greenhouse sederhana pada usahatani sayuran agar dapat mencegah dan melindungi tanaman dari cuaca yang ekstrem serta melakukan pencatatan dalam usahatani.

\section{DAFTAR PUSTAKA}

Badariah N, Surjasa D, Trinugraha Y. 2012. Analisa supply chain risk management berdasarkan metode failure mode effects analysis (FMEA). Jurnal Teknik Industri 2(2):110-118

Crane, L, Gene Gantz, Steve Isaacs, Doug Jose, Rod Sharp. 2013. Understanding Agricultural Risks: Production, Marketing, Financial, Legal, and Human._Second Edition, 2013. Extension Risk Management Education and Risk Management Agency with funding by United States Department of Agriculture

Elton, Edwin, and Gruber. 1995. Modern Portofolio Theory And Investment Analysis. Fifth Edition. New York : John Wiley and Sosc Inc.

Fauziyah, Elys. 2010. Pengaruh Perilaku Petani dalam Menghadapi Risiko
Produksi terhadap Alokasi Input Usahatani Tembakau: Pendekatan Fungsi Produksi Frontir Stokastik. Disertasi Program Doktor. Sekolah Pascasarjana IPB

Harwood J., Richard Heifner, Keith Coble, Janet Perry, Agapi. 1999. Managing Risk in Farming: Concepts, Research, and Analysis. Somwaru. Market and Trade Economics Division and Resource Economics Division, Economic Research Service, U.S. Department of Agriculture. Agricultural Economic Report No. 774.

Kementrian Pertanian. 2016. Balai Besar Penelitian Tanaman

Padi.Http://bbpadi.litbang.pertanian.g o.id. Diakses 15 Februari 2017

Permatasari, RDP. 2013. Analisis Risiko Diversifikasi Sayuran Indegenous (Kasus: Usahatani Anggota Kelompok Tani Mitra Tani Parahyangan, Kabupaten Cianjur). [Skripsi]. Bogor : Departemen Agribisnis, Institut Pertanian Bogor.

Saptana, Arief Daryanto, Heny K. Daryanto, Kuntjoro. 2010. Strategi Manajemen Risiko Petani Cabai merah pada Lahan Sawah Dataran Rendah di Jawa Ttengah. Jurnal Manajemen dan Agribisnis 7 (2): 115131.

Suryadi, Kusmana. 2010. Mengenal Sayuran Indegenous. Bandung: Balai Penelitian Sayuran

Soetiarso, T.A. 2010. Persepsi dan Preferensi Konsumen terhadap Atribut Produk beberapa Sayuran Minor. J.Hort. 20(3): 299-312,2010 
Lampiran 1 Karakteristik Petani di Kecamatan Kadudampit, 2017.

\begin{tabular}{|c|c|c|c|}
\hline No & Kondisi & Jumlah Petani & Presentase $(\%)$ \\
\hline \multirow[t]{7}{*}{1} & Kelompok Umur (Tahun) & & \\
\hline & $<30$ & - & 0 \\
\hline & $30-40$ & 6 & 14 \\
\hline & $41-50$ & 12 & 29 \\
\hline & $51-60$ & 14 & 33 \\
\hline & $>60$ & 10 & 24 \\
\hline & Jumlah & 42 & 100 \\
\hline \multirow[t]{7}{*}{2} & Tingkat Pendidikan & & \\
\hline & Tidak Tamat SD & 11 & 26 \\
\hline & Tamat SD/sederajat & 23 & 55 \\
\hline & Tamat SMP/sederajat & 4 & 10 \\
\hline & Tamat SMA/sederajat & 4 & 10 \\
\hline & Perguruan Tinggi & - & - \\
\hline & Jumlah & 42 & 100 \\
\hline \multirow[t]{6}{*}{3} & Luas Lahan ( Ha) & Jumlah Petani & Presentase (\%) \\
\hline & $<0,25$ & 24 & 57 \\
\hline & $0,25-<0,5$ & 8 & 19 \\
\hline & $0,51-<1$ & 8 & 19 \\
\hline & $>1$ & 2 & 5 \\
\hline & Jumlah & 42 & 100 \\
\hline \multirow[t]{6}{*}{4} & Pengalaman Usahatani & Jumlah Petani & Presentase $(\%)$ \\
\hline & $<1$ Tahun & - & 0 \\
\hline & $1-<5$ Tahun & 3 & 7 \\
\hline & $5-<10$ Tahun & 5 & 12 \\
\hline & $>10$ Tahun & 34 & 81 \\
\hline & Jumlah & 42 & 100 \\
\hline \multirow[t]{6}{*}{5} & Jumlah Tanggungan Keluarga & Jumlah Petani & Presentase $(\%)$ \\
\hline & $0-2$ Orang & 20 & 48 \\
\hline & 3 - 5 Orang & 20 & 48 \\
\hline & 6 - 8 Orang & 2 & 5 \\
\hline & $>8$ Orang & - & 0 \\
\hline & Jumlah & 42 & 100 \\
\hline
\end{tabular}


Lampiran 2 Rata-rata Biaya Produksi dan Pendapatan Sayuran Per Luas Lahan 0,32 Ha Per Satu Periode Tanam (6 Bulan) di Kecamatan Kadudampit, 2017.

\begin{tabular}{|c|c|c|c|c|c|c|}
\hline Keterangan & Kemangi & $\%$ & Poh-pohan & $\%$ & Reundeu & $\%$ \\
\hline \multicolumn{7}{|l|}{ Biaya Variabel (Rp) } \\
\hline a. Benih & 55.066 & 1,02 & 7.778 & 0,32 & 3.889 & 0,13 \\
\hline b. Pupuk kandang & 304.514 & 6 & - & 0 & - & 0 \\
\hline c. Pupuk urea & 153.566 & 2,83 & 40.278 & 1,67 & 20.139 & 0,67 \\
\hline d. Pupuk ponska & 161.138 & 2,97 & - & 0 & - & 0 \\
\hline e. Pupk ZA & 41.250 & 0,76 & - & 0 & - & 0 \\
\hline f. Pupuk KCL & 168.500 & 3,11 & - & 0 & - & 0 \\
\hline g. Pupuk TSP & 167.438 & 3,09 & - & 0 & - & 0 \\
\hline h. Pupuk lainnya & 50.000 & 0,92 & - & 0 & - & 0 \\
\hline i. $\quad$ Pestisida 1 & 96.521 & 1,78 & - & 0 & - & 0 \\
\hline j. $\quad$ Pestisida 2 & 144.904 & 2,67 & - & 0 & - & 0 \\
\hline k. Pestisida 3 & 113.185 & 2,09 & - & 0 & - & 0 \\
\hline 1. Pengikatan & 200.904 & 3,71 & 6.875 & 0,29 & 2.292 & 0,08 \\
\hline $\begin{array}{l}\text { m. Tenaga kerja } \\
\text { dibayar } \\
\text { n. Tenaga kerja }\end{array}$ & 3.761 .122 & 69,42 & 313.802 & 13,02 & 313.802 & 13,59 \\
\hline diperhitungkan & - & - & 2.041 .406 & 85 & 1.441 .406 & 86 \\
\hline $\begin{array}{l}\text { Biaya variabel total } \\
\text { (Rp) }\end{array}$ & 5.418 .108 & 100 & 2.410 .139 & 100 & 1.781 .528 & 100 \\
\hline Biaya Tetap (Rp) & & & & & & \\
\hline a. Penyusutan & 100.054 & 100 & 104.743 & 100 & 52.372 & 100 \\
\hline Biaya Tetap Total & 100.054 & 100 & 104.743 & 100 & 52.372 & 100 \\
\hline Biaya Produksi & 5.518 .162 & & 2.514 .882 & & 1.833 .900 & \\
\hline Penerimaan & 11.404 .615 & & 4.882 .500 & & 2.362 .500 & \\
\hline Pendapatan & 5.886 .453 & & 2.367 .618 & & 528.600 & \\
\hline $\begin{array}{l}\text { Pendapatan per } \\
\text { bulan }\end{array}$ & 981.075 & & 394.603 & & 88.100 & \\
\hline $\mathrm{R} / \mathrm{C}$ & 2,06 & & 1,94 & & 1,28 & \\
\hline
\end{tabular}

Lampiran 3 Sumber Risiko Produksi Sayuran Indigenous dan Komersial, 2017.

\begin{tabular}{|c|c|c|c|c|c|c|}
\hline \multirow{2}{*}{$\begin{array}{c}\text { Sumber } \\
\text { Risiko }\end{array}$} & \multicolumn{5}{|c|}{ Jumlah Petani } & \multirow[t]{2}{*}{ Jumlah } \\
\hline & 1 & 2 & 3 & 4 & 5 & \\
\hline \multirow{3}{*}{$\begin{array}{l}\text { Iklim/Cuaca } \\
\text { Hama \& } \\
\text { Penyakit } \\
\text { Kualitas Benih }\end{array}$} & 0 & 0 & 1 & 7 & 34 & 42 \\
\hline & 0 & 1 & 2 & 8 & 31 & 42 \\
\hline & 0 & 1 & 6 & 24 & 11 & 42 \\
\hline \multirow[t]{2}{*}{ Sumber Risiko } & \multicolumn{5}{|c|}{ Skor } & \multirow[t]{2}{*}{ Jumlah } \\
\hline & 1 & 2 & 3 & 4 & 5 & \\
\hline \multirow{3}{*}{$\begin{array}{l}\text { Iklim/Cuaca } \\
\text { Hama \& } \\
\text { Penyakit } \\
\text { Kualitas Benih } \\
\end{array}$} & 0 & 0 & 3 & 28 & 170 & 201 \\
\hline & 0 & 2 & 6 & 32 & 155 & 195 \\
\hline & 0 & 2 & 18 & 96 & 55 & 171 \\
\hline
\end{tabular}

